\title{
Assessing Trainee's Profile for Better Execution of Livestock Training Course
}

\author{
Navjot Kaur ${ }^{1}$, Parminder Singh ${ }^{2 *}$, Rajesh Kasrija ${ }^{2}$ and H.K. Verma ${ }^{3}$ \\ ${ }^{1}$ Department of Health and Family Welfare, Punjab, India \\ ${ }^{2}$ Department of Veterinary and Animal Husbandry Extension, Education, Guru Angad Dev \\ Veterinary and Animal Sciences University, Ludhiana, Punjab, India \\ ${ }^{3}$ Director Extension Education, Guru Angad Dev Veterinary and Animal Sciences University, \\ Ludhiana, Punjab, India \\ *Corresponding author
}

\section{A B S T R A C T}

The present study was conducted on livestock farmers, who have attended the training courses at Guru Angad Dev Veterinary and Animal Sciences University Ludhiana. The

\section{Keywords}

Dairy, GADVASU,

Piggery, Poultry,

Training, Trainee

Article Info

Accepted:

07 October 2018

Available Online:

10 November 2018 data were collected by personally interviewing the trainees who have attended pig farming $(n=69)$, dairy $(n=51)$ and poultry farming $(n=40)$ training course. In piggery training course, $46.37 \%$ trainees were in the age group of more than 40 years and $44.93 \%$ trainees were matriculates. In dairy training, $52.94 \%$ trainees belonged to age group less than 25 years. $52.94 \%$ in dairy and $52.50 \%$ in poultry training were senior secondary. There was significant relationship $(\mathrm{P}<0.05)$ between age and education among poultry trainees. In piggery, dairy and poultry training $78.26 \%, 60.78 \%$ and $50.00 \%$ trainees, respectively were from joint families. In piggery and poultry training $62.32 \%$ and $75.00 \%$ trainees, respectively were married. In dairy training, $62.75 \%$ trainees were unmarried. In piggery and poultry training majority of the trainees were having 2-4 years of experience. $47.82 \%$ and $77.50 \%$ trainees from piggery and poultry, respectively were having high level of mass media exposure. There was significant relationship $(\mathrm{P}<0.01)$ between social participation and mass media exposure.

\section{Introduction}

Training is the process by which the desired knowledge, skills, attitude and ideas are included, fastened and reinforced in an organism (Lynton and Pareek, 1990). Guru Angad Dev Veterinary and Animal Sciences University (GADVASU), Ludhiana regularly organizes trainings for creating awareness, educating and motivating the farmers, farm women and rural youth to adopt livestock entrepreneurship viz. dairy farming, poultry farming and pig farming. A well designed and executed training programme for farmers can ensures dissemination of new technologies. For bringing these desirable changes, the assessment of trainer's profile is must, which can give idea about need, interest, 
requirement, perceptions and aspirations of trainees about a training course. The Literature related with this subject is scanty. So, present study was planned to assess the demographic and communication profile of trainees who has attended Specialized training course from GADVASU, Ludhiana

\section{Materials and Methods}

The present study was conducted on farmers, who have attended the training courses for pig/ dairy and poultry farming at Guru Angad Dev Veterinary and Animal Sciences University Ludhiana. The data were collected by personally interviewing the trainees who have attended pig farming $(n=69)$, dairy $(n=$ $51)$ and poultry farming $(n=40)$ training course.

Extension contacts were studied on a three point continuum i.e. regularly, sometimes and never with arbitrary scores of 3,2 and 1, respectively. Mass media exposure was studied on a three point continuum viz., regularly, sometimes and never with arbitrary scores of 3,2 and 1, respectively. For Social participation, the response of the respondents was taken in terms of dichotomous response i.e. yes or no. The data was analysed with the help of statistical software Statistical Package for the Social Sciences (SPSS) Version 17.

\section{Results and Discussion}

\section{Demographic profile of trainees}

A perusal of Table 1 indicates that in piggery training course, higher percentage (46.38) of trainees was in the age group of more than 40 years. In dairy training, 52.94 per cent of the trainees belonged to age group less than 25 years. This could be due to the reason that most trainees passed out or dropped out were young and had taken some responsibility of dairy farming. However, in poultry training more than half of the trainees (52.50 per cent) belonged to age group of 25-40 years. Similar results were reported in earlier studies by Kumar (2009) and Pauline and Karthikeyan (2015).

In piggery training, 44.93 per cent of the trainees were matriculates. However, 52.94 per cent in dairy and 52.50 per cent in poultry training were having education level of senior secondary. It could be due to the fact that the eligibility for registration of this course is matric and all the trainees had above matric level of education. The results were supported with the findings of Singh (2013).

In piggery, dairy and poultry training, 78.26, 60.78 and 50 per cent of the trainees, respectively were from joint families whereas $21.74,39.22$ and 50 per cent of the trainees belonged to nuclear families in respective training programs. The higher percentage of the trainees from the joint family group in the present study illustrates that joint families still exist in rural areas. In piggery, dairy and poultry trainings, $30.43,23.52$ and 42.50 per cent trainees, respectively were with the family size as up to 4 . In all the trainings more than 50 per cent of the trainees had family members 5-8, whereas 7.25, 17.65, and 7.50 per cent of the trainees had more than 8 members in the family in the respective training groups. It could be due to the reason that most of the trainees belonged to joint families.

In piggery and poultry training 62.32 and 75.00 per cent of the trainees, respectively were married (Table 1). It could be due to the reason that most of the trainees belonged to 25-40 and more than 40 years of age, respectively. The results further revealed that in dairy training 62.75 per cent of the trainees were unmarried. It might be due to the reason that most of the trainees belonged to less than 25 years of age as the average age of marriage 
in India is 26 years (Singh 2013). In piggery and poultry farming majority of the trainees were having 2-4 years of experience. Similar findings were observed by Pauline and Karthikeyan (2015). 43.14 per cent of the trainees had experience above 4 years while 35.29 per cent of the trainees had experience of dairy farming between 1-2 years. 21.57 per cent of the trainees had dairy farming experience of 2-4 years. It indicates that the trainees liked to adopt dairy farming as subsidiary and commercial level enterprise.

Chi-square $\left(\chi^{2}\right)$ test was applied to assess relationship between Age and Education of trainees. There was significant relationship between age and education among poultry trainees at 5\% level of significance (Table 2).

\section{Communication profile of trainees}

\section{Extension Contacts}

To update their knowledge about farming the trainees had contacted with different extension functionaries. Response of the trainees was recorded and has been presented (Table 3). It was observed that 53.62, 52.94 and 80.00 per cent of the piggery, dairy and poultry trainees, respectively contacted university experts sometimes however 11.59, 31.37 and 5.00 per cent of the piggery, dairy and poultry trainees, respectively never contacted University experts. Similar results were reported by Singh (2013).

40.57, 62.75 and 80.00 per cent of the piggery, dairy and poultry trainees, respectively had contacted local Veterinary Officers sometimes. 49.27 and 76.47 per cent of the piggery and dairy trainees, respectively never contacted KVK scientists. However 85.00 per cent of the poultry trainees regularly contacted KVK scientists.72.46, 70.59 and 85.00 per cent of the piggery, dairy and poultry trainees never contacted District Extension Specialist. 42.02 and 85.00 per cent of piggery and poultry trainees, respectively never contacted Veterinary Pharmacist, however 43.14 per cent of the dairy trainees contacted sometimes. Similar findings were also observed by Singh (2013) and Pauline and Karthikeyan (2015).

Table.1 Demographic profile of the trainees

\begin{tabular}{|c|c|c|c|c|}
\hline $\begin{array}{l}\text { Profile of the } \\
\text { Trainees }\end{array}$ & Category & $\begin{array}{l}\text { Piggery Training } \\
\qquad(n=69)\end{array}$ & $\begin{array}{l}\text { Dairy Training } \\
\quad(n=51)\end{array}$ & $\begin{array}{l}\text { Poultry Training } \\
\qquad(\mathrm{n}=40)\end{array}$ \\
\hline \multirow[t]{3}{*}{ Age (Years) } & $<25$ & $21(30.43)$ & 27 (52.94) & $17(42.50)$ \\
\hline & $25-40$ & $16(23.19)$ & $13(25.49)$ & $21(52.50)$ \\
\hline & $>40$ & $32(46.38)$ & $11(21.56)$ & $2(5.00)$ \\
\hline \multirow[t]{4}{*}{ Education } & Up to Matric & $31(44.93)$ & $5(9.80)$ & $8(20.00)$ \\
\hline & Senior Secondary & $17(24.64)$ & $27(52.94)$ & $21(52.50)$ \\
\hline & Graduation & $13(18.84)$ & $14(27.45)$ & $9(22.50)$ \\
\hline & Post-Graduation & $8(11.59)$ & $5(9.80)$ & $2(5.00)$ \\
\hline \multirow[t]{2}{*}{ Family Type } & Joint & $54(78.26)$ & $31(60.78)$ & $20(50.00)$ \\
\hline & Nuclear & $15(21.74)$ & $20(39.22)$ & $20(50.00)$ \\
\hline \multirow[t]{3}{*}{ Size } & Up to 4 & $21(30.43)$ & $12(23.52)$ & $17(42.50)$ \\
\hline & $5-8$ & $43(62.32)$ & $30(58.82)$ & $20(50.00)$ \\
\hline & $>8$ & $5(7.25)$ & $9(17.65)$ & $3(7.50)$ \\
\hline \multirow[t]{3}{*}{ Marital Status } & Married & $43(62.32)$ & $19(37.25)$ & $30(75.00)$ \\
\hline & Unmarried & $26(37.68)$ & $32(62.75)$ & $10(25.00)$ \\
\hline & Divorced & $0(0)$ & $0(0)$ & $0(0)$ \\
\hline \multirow{3}{*}{$\begin{array}{l}\text { Farming } \\
\text { Experience } \\
\text { (years) }\end{array}$} & $1-2$ & $27(39.13)$ & $18(35.29)$ & $2(5.00)$ \\
\hline & $2-4$ & $39(56.52)$ & $11(21.57)$ & $38(95.00)$ \\
\hline & $>4$ & $3(4.35)$ & $22(43.14)$ & $0(0)$ \\
\hline
\end{tabular}

Figure in parenthesis indicate percentage 
Table. 2 Relationship between age and education of trainees

\begin{tabular}{|c|c|c|}
\hline Piggery & Dairy & Poultry \\
\hline $\mathbf{0 . 0 7 8}$ & 0.106 & $0.267^{*}$ \\
\hline \multicolumn{2}{|c|}{$\mathbf{0 . 1 3 1}$} \\
\hline
\end{tabular}

(*): Significant at 5\%

Table.3 Sources of information

\begin{tabular}{|c|c|c|c|c|}
\hline Extension Sources & Criterion & Piggery training & Dairy Training & $\begin{array}{c}\text { Poultry } \\
\text { Training }\end{array}$ \\
\hline University experts & Never & $8(11.59)$ & $16(31.37)$ & $2(5.00)$ \\
\cline { 2 - 5 } & Sometimes & $37(53.62)$ & $27(52.94)$ & $32(80.00)$ \\
\hline \multirow{2}{*}{$\begin{array}{c}\text { Veterinary } \\
\text { officers }\end{array}$} & Regularly & $24(34.78)$ & $8(15.69)$ & $6(15.00)$ \\
\hline KVer & $21(30.43)$ & $11(21.56)$ & $3(7.50)$ \\
\hline KV scientists & Sometimes & $28(40.57)$ & $32(62.75)$ & $32(80.00)$ \\
\hline & Regularly & $20(28.98)$ & $8(15.69)$ & $5(12.50)$ \\
\hline District. & Never & $34(49.27)$ & $39(76.47)$ & $2(5.00)$ \\
\hline Extension & Sometimes & $22(31.88)$ & $8(15.69)$ & $4(10.00)$ \\
\hline Specialist & Negularly & $13(18.84)$ & $4(7.84)$ & $34(85.00)$ \\
\hline Veterinary & Sometimes & $50(72.46)$ & $36(70.59)$ & $34(85.00)$ \\
\hline Pharmacists & Regularly & $7(10.14)$ & $12(23.53)$ & $4(10.00)$ \\
\hline & Never & $29(42.02)$ & $3(5.88)$ & $2(5.00)$ \\
\hline & Sometimes & $21(30.43)$ & $22(43.14)$ & $34(85.00)$ \\
\hline
\end{tabular}

Figure in parenthesis indicate percentage

Table.4 Mass media exposure

\begin{tabular}{|c|c|c|c|c|}
\hline Mass media source & Criterion & Piggery & Dairy & Poultry \\
\hline \multirow{2}{*}{ Farm broadcast } & Never & $10(14.49)$ & $28(54.90)$ & $2(5.00)$ \\
\cline { 2 - 5 } & Sometimes & $26(37.68)$ & $19(37.25)$ & $7(17.50)$ \\
\hline \multirow{2}{*}{ Farm Telecast } & Regularly & $33(47.82)$ & $4(7.84)$ & $31(77.50)$ \\
& Never & $42(60.86)$ & $2(3.92)$ & $15(37.50)$ \\
\hline & Sometimes & $21(30.43)$ & $33(64.71)$ & $15(37.50)$ \\
\hline Vigyanak Pashu & Regularly & $6(8.69)$ & $16(31.37)$ & $10(25.00)$ \\
\hline Palan & Never & $26(37.68)$ & $18(35.29)$ & $2(5.00)$ \\
\hline Newspapers & Sometimes & $21(30.43)$ & $22(43.14)$ & $7(17.50)$ \\
\hline & Regularly & $22(31.88)$ & $11(21.57)$ & $31(77.50)$ \\
\hline & Never & $48(69.56)$ & $7(13.73)$ & $2(5.00)$ \\
\hline Internet & Sometimes & $14(20.28)$ & $20(39.22)$ & $4(10.00)$ \\
\hline & Regularly & $7(10.14)$ & $24(47.06)$ & $34(85.00)$ \\
\hline & Never & $9(13.04)$ & $42(82.35)$ & $5(12.50)$ \\
\hline & Sometimes & $2(2.89)$ & $5(9.80)$ & $7(17.50)$ \\
\hline
\end{tabular}

Figure in parenthesis indicate percentage 
Table.5 Distribution of the trainees according to their participation in social organizations

\begin{tabular}{|l|c|c|c|}
\multicolumn{1}{|c|}{ Social Participation } & Piggery Training & \multicolumn{1}{c|}{$\begin{array}{c}\text { Dairy } \\
\text { Training }\end{array}$} & Poultry Training \\
\hline $\begin{array}{l}\text { Progressive Dairy } \\
\text { Farmers Association }\end{array}$ & $20(28.99)$ & $10(19.61)$ & $0(0)$ \\
\hline Milk Coop. Society & $22(31.38)$ & $16(31.37)$ & $1(2.50)$ \\
\hline Village Panchayat & $16(23.19)$ & $5(9.80)$ & $0(0)$ \\
\hline Marketing Committee & $7(10.14)$ & $2(3.92)$ & $0(0)$ \\
\hline Religious Committee & $20(28.99)$ & $13(25.49)$ & $3(7.50)$ \\
\hline ATMA Advisory Comm. & $5(7,25)$ & $3(5.88)$ & $0(0)$ \\
\hline KVK Advisory Committee & $9(13.04)$ & $3(5.88)$ & $0(0)$ \\
\hline
\end{tabular}

Figure in parenthesis indicate percentage

Table.6 Relationship between social participation and mass media exposure of trainees

\begin{tabular}{|c|c|c|}
\hline Piggery & Dairy & Poultry \\
\hline $\mathbf{0 . 2 7 2 *}$ & $0.411 * *$ & $0.246^{*}$ \\
\hline
\end{tabular}

(*): significant at $5 \%$

$(* *)$ : significant at $1 \%$

\section{Mass media exposure}

The data (Table 4) revealed that 47.82 and 77.50 per cent of the trainees from piggery and poultry training respectively had listened farm broadcast regularly. However 54.90 per cent of the trainees from dairy training had never listened farm broadcast. 60.86 and 37.50 per cent of trainees in piggery and poultry training course had never watched farm telecast, but 64.71 per cent of the dairy trainees had sometimes watched farm telecast. Chauhan and Kansal 2014 also reported that preference for farm telecast was higher by dairy farmers. In piggery training course, 37.68 per cent of the trainees had never read GADVASU monthly Punjabi magazine, Vigyanak Pashu Palan, but in dairy and poultry training course 43.14 and 77.50 per cent of the trainees had sometimes and regularly, respectively read the Vigyanak Pashu Palan.

Only 20.28 per cent of the trainees in poultry training course had sometimes read the newspaper whereas in dairy and poultry training course 47.06 and 85.00 per cent of the trainees, respectively had regularly read the newspapers.

$84.05 \%$ and $70.00 \%$ of the trainees in piggery and poultry training course, respectively had regularly used internet but in dairy training course $82.35 \%$ of the trainees had never used internet. These results are in line with Chauhan and Kansal (2014).

\section{Social participation}

Social participation of the trainees was taken as a membership of any formal or informal organization or holding of any post in the organization. Social participation of the trainees is shown in Table 5. It is clear from the data that about 31.00 per cent of the trainees from piggery and dairy training were members of Village level milk producers cooperative society. This may be due to the reason that they were dependent on the cooperative society for sale of milk, purchase 
of feed for animals and veterinary staff of dairy cooperative who personally visited farmers. These findings are in line with Chauhan and Kansal (2014). 5.88 per cent of the trainees from dairy training were members of ATMA and KVK advisory committee and whereas 7.20 and 13.04 per cent from piggery training were members of ATMA and KVK advisory committee, respectively. It was also observed that about 28.99 per cent from piggery training and 25.49 per cent from dairy were members of Religious Committee whereas 23.19 and 9.80 per cent of the trainees from piggery and dairy training respectively were the members of Village Panchayat. About 28.99 and 19.61 per cent of the trainees from piggery and dairy training respectively were members of Progressive Dairy Farmers Association. 10.14 and 3.92 per cent from Piggery and dairy training respectively were of marketing committee. 2.50 and 7.50 per cent from Poultry training were members of village panchayat and religious committee. The findings are in accordance with Pauline and Karthikeyan (2015).

Chi-square $\left(\chi^{2}\right)$ test was applied to assess relationship between social participation and mass media exposure of trainees. There was significant relationship between social participation and mass media exposure at $5 \%$ level however it was significant at $1 \%$ level among dairy trainees (Table 6).

The present study highlights that most of the trainees were young, educated, belonged to joint families, married. There was significant relationship $(\mathrm{P}<0.05)$ between age and education among poultry trainees. There was significant relationship $(\mathrm{P}<0.01)$ between social participation and mass media exposure for Piggery, Dairy and Poultry farmers. These tyrainer's profile parameters should be taken in to consideration while organizing future training programmes.

\section{References}

Chauhan M and Kansal S K. 2014. Most preferred animal husbandry information sources and channel among dairy farmers of Punjab. Indian Research Journal of Extension Education, (Special issue on Veterinary Research \& Extension) 14(4) November 33-36.

Kumar D. 2009. Evaluation of selected field trainees of Dairy Development Department of Punjab. M.V.Sc. Thesis, Guru Angad Dev Veterinary and Animal Sciences University, Ludhiana, India.

Lynton R P and Pareek U. 1990. Training for Development. $\quad$ Pp 1-2, Visitor Publication, New Delhi.

Pauline A Anitha, and Karthikeyan C. 2015 Farmer to farmer extension through farmer friend. Indian Research Journal of Extension Education 15(2): 95-99.

Singh K. 2013. Reactions of the trainees about three months training course of practical education in agriculture for young farmers organized by PAU, Ludhiana. M.Sc. Thesis, Punjab Agricultural University, Ludhiana, India.

\section{How to cite this article:}

Navjot Kaur, Parminder Singh, Rajesh Kasrija and Verma, H.K. 2018. Assessing Trainee's Profile for Better Execution of Livestock Training Course. Int.J.Curr.Microbiol.App.Sci. 7(11): 561-566. doi: https://doi.org/10.20546/ijcmas.2018.711.067 